\title{
Serum Adenosine Deaminase Values In Healthy People
}

Journal of Bioscience \& Biomedical Engineering

Short Communication

\author{
Irena I Gencheva ${ }^{1 *}$, Iren A Angelova ${ }^{2}$ and Adelaida L Ruseva ${ }^{1}$
}

${ }^{1}$ University Hospital “Dr. Georgi Stranski” - Pleven, Clinical
Laboratory

${ }^{2}$ Medical University - Pleven

\author{
"Correspondence author \\ Irena I. Gencheva \\ Department of Clinical Laboratory \\ Clinical Immunology and Allergology \\ Medical University - Pleven - 1 Saint Kliment Ohridski \\ Str. Pleven \\ 5800 \\ Bulgaria
}

Submitted : 10 Jun 2020 ; Published : 29 Jun 2020

\section{Summary}

The purpose of this study is to determine the activity of serum adenosine deaminase (ADA) in healthy people, in connection with significant differences in published reference ranges from different authors.

In our study, we examined 160 healthy subjects aged 18 to 84 , of whom 64 were men and 96 women. We have determined serum adenosine deaminase levels using a method based on the ability of the enzyme adenosine deaminase to catalyze the deamination of adenosine to inosine and ammonia. The catalytic concentration is determined spectrophotometrically by the rate of reduction of NADH measured at $340 \mathrm{~nm}$.

We found that normal serum ADA values among our healthy subjects are higher than the recommended reference range for the method we use, namely below $18 \mathrm{U} / 1$. Using the percentile method, we worked out the following reference ranges: for women $14.53-25.73 \mathrm{U} / 1$ and for men $18.46-27.50 \mathrm{U} / 1$. For women, the mean value is $21.07 \mathrm{U} / 1$, and for men 21.30 $\mathrm{U} / 1$. At $95 \% \mathrm{CI}$, the serum ADA values of almost all subjects included in the study are within the recommended and other authors range of $11.50-25.00 \mathrm{U} / 1$.

\section{Introduction}

Adenosine deaminase (ADA) is an enzyme involved in purine metabolism. This enzyme is needed for the secretion of adenosine from food and for the exchange of nucleic acids in tissues. Its main function in people is the development and maintenance of the immune system. ADA is considered to be one of the major enzymes of purine metabolism. Adenosine deaminase deficiency leads to pulmonary fibrosis, suggesting that chronic exposure to high levels of adenosine may

exacerbate inflammatory reactions instead of suppress them $[1,2]$.

Using the high activity of the enzyme in diseases with stimulated cellular immunity, such as tuberculosis, the study and report of elevated ADA values significantly above $20 \mathrm{U} / \mathrm{L}$ contributes to the diagnosis of tuberculosis and especially to tuberculous pleurisy and meningitis [3,4]. Serum ADA levels can be measured using high performance liquid chromatography, enzymatic or colorimetric techniques.

\section{Purpose}

The aim of our study was to determine the activity of adenosine deaminase (ADA) in the serum of healthy individuals, due to the significant differences in the published reference ranges by different authors.

\section{Patients and Methods}

In our study, we examined 160 healthy individuals aged 18 to 84 years, of whom 64 were men and 96 were women. Serum levels of adenosine deaminase were determined by a method, based on the enzyme's ability to catalyze the deamination of adenosine to inosine and ammonia. The catalytic concentration was determined spectrophotometrically by the NADH reduction rate measured at $340 \mathrm{~nm}$.

\section{Discussion}

We found that the normal serum ADA values in the healthy individuals we studied were higher than the recommended reference ranges for the method we used, namely below 18 
U/1. Using the percentile method, we developed the following reference ranges: for women $14.53-25.73 \mathrm{U} / 1$ (Fig. 1) and for men 18.46 - $27.50 \mathrm{U} / 1$ (Fig. 2).

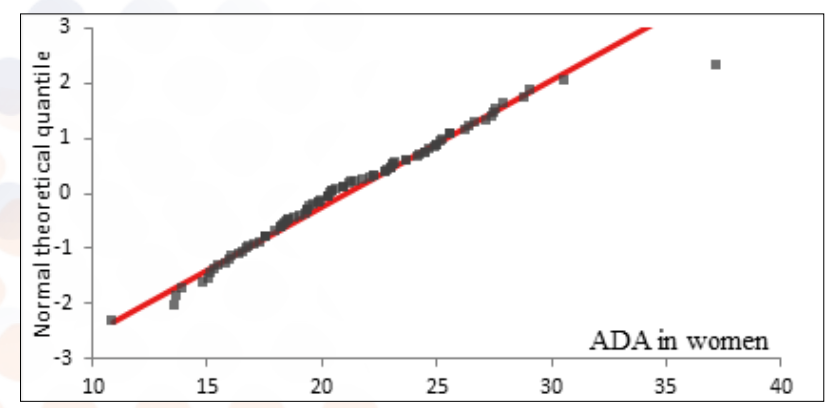

Figure 1

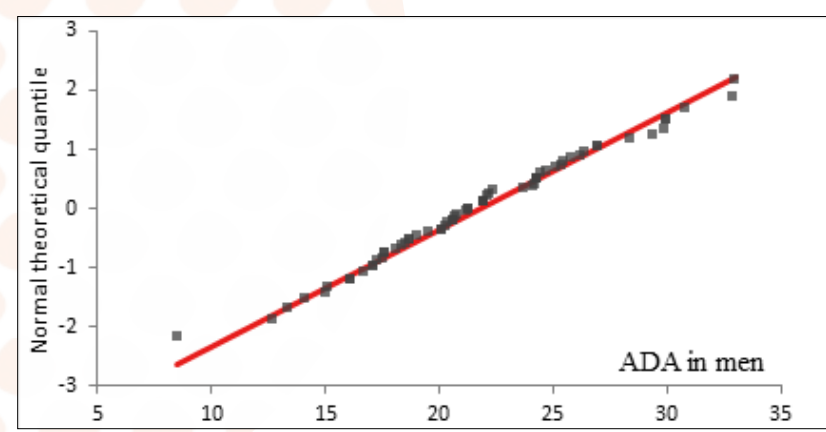

Figure 2

The mean value for women is $21.07 \mathrm{U} / \mathrm{l}$, and for men 21.30 U / 1. At 95\% CI, serum ADA values for almost all subjects, included in the study, were within the ranges recommended by other authors, namely in the range of $11.50-25.00 \mathrm{U} / 1$ [5-8].

\section{Conclusion}

In our study, we found that the values for serum adenosine deaminase in healthy men and women are higher than the recommended reference ranges compared to the method we use, but are in within the limits recommended by other authors.

\section{References}

1. Goto M, Noguchi Y, Koyama H, Hira K, Shimbo T, Fukui T (2003) Diagnostic value of adenosine deaminase in tuberculous pleural effusion: a meta-analysis. Ann Clin Biochem 40(4): 374-381.[PubMed] [doi: 10.1258/000456303766477011]

2. Srinivasa Rao K, Anandkumar H, Rudresh B M, Srinivas T, Harish Bhat K (2010) A comparative study and evaluation of serum adenosine deaminase activity in the diagnosis of pulmonary tuberculosis. Biomedical Research 2: 189-194.

3. Hassanein K, Hosny H, Mohamed R, Abd El-Moneim W (2010) Role of adenosine deaminase (ADA) in the diagnosis of pulmonary tuberculosis. Egypt J Bronchol 4: 11-8.

4. Pandey R, Tamrakar D, Jaiswal S, Sharma A, Koju S, Duwal SR, et al. (2016) Serum adenosine deaminase:
A novel biomarker tool for the diagnosis of tuberculosis. Biosci Biotech Res Asia 13: 551-556.

5. Afrasiabian S, Mohsenpour B, Bagheri KH, Sigari N, Aftabi K (2013) Diagnostic value of serum adenosine deaminase level in pulmonary tuberculosis 2012-2014.

6. Kuyucu N, Karakurt C, Bilaloglu E, Karacan C, Tezic $T$ (1999) Adenosine deaminase in childhood pulmonary tuberculosis:diagnostic value in serum. J Trop Pediatr 45: 245-247.

7. Saini V, Lokhande B, Jaswal S, Aggarwal D, Garg K, Kaur $\mathrm{J}$ (2018) Role of serum adenosine deaminase in pulmonary tuberculosis. Indian J Tuberc 65: 30-34.

8. Zafer Kartaloglu, Oguzhan Okutan, Erkan Bozkanat, M Harun Ugan, Ahmet Ilvan (2006) The course of serum adenosine deaminase levels in patients with pulmonary tuberculosis.Med Sci Monit 12(11): CR 476- 480.
Copyright: (C2020 Irena I. Gencheva. This is an open-access article distributed under the terms of the Creative Commons Attribution License, which permits unrestricted use, distribution, and reproduction in any medium, provided the original author and source are credited. 